Volume 12 | Issue 3

August 2021

\title{
The Historical Roots of Social Assistance: An Inadequate Response to the Colonial Destruction of Mi'kmaw Livelihood in Nova Scotia
}

\author{
Declan Cullen \\ George Washington University, United States, drcullen@gwu.edu \\ Heather Castleden \\ Queen’s University, Canada, Heather.Castleden@queensu.ca \\ Fred Wien \\ Dalhousie University, Canada, frederic.wien@dal.ca
}

Recommended Citation

Cullen, D., Castleden, H., \& Wien, F. (2021). The historical roots of social assistance: An inadequate response to the colonial destruction of Mi'kmaw livelihood in Nova Scotia. The International Indigenous Policy Journal, 12(3).

https://doi.org/10.18584/iipj.2021.12.3.10202 


\title{
The Historical Roots of Social Assistance: An Inadequate Response to the Colonial Destruction of Mi'kmaw Livelihood in Nova Scotia
}

\begin{abstract}
Social assistance and related programs are an important part of life in the $13 \mathrm{Mi}$ 'kmaq communities of Nova Scotia. Given the substantive importance of social assistance and related programs in Mi'kmaq communities, it is surprising how little research has been conducted on the subject. This research aims to understand the origins of economic dependence and the related emergence of social assistance among the Mi'kmaq in Nova Scotia. We identify key historical periods and processes that have shaped the current policy landscape. A defining characteristic of social policy on reserve has been the fact that First Nations themselves have had very little say in how programs such as social assistance are designed and delivered. There is hope that a more self-determined and holistic approach may emerge.
\end{abstract}

\section{Keywords}

Mi'kmaq, social assistance, economic dependence, colonialism, self-determination

\section{Acknowledgments}

The historical research reported here draws from a larger research project funded by the Canadian Institutes of Health Research and carried out with the cooperation of the Mi'kmaq Rights Initiative (Kwilmu'kw Maw-

klusuaqn). Members of the research team include Cheryl Bartlett, Anita Benoit, Heather Castleden, Jeff Denis, Debbie Martin, Jane McMillan, Carla Moore, Fred Wien, and Tuma Young.

\section{Creative Commons License (2) $\odot \Theta \Theta$}

This work is licensed under a Creative Commons Attribution-Noncommercial-No Derivative Works 4.0 License. 


\section{The Historical Roots of Social Assistance: An Inadequate Response to the Colonial Destruction of Mi'kmaw Livelihood in Nova Scotia}

Social assistance, also known as income support, income assistance, and welfare, among other names, is a significant part of life in Nova Scotia's 13 Mi'kmaq communities. ${ }^{1}$ In the most recent First Nations Regional Health Survey, conducted on reserve by the Union of Nova Scotia Indians (2013), 52\% of adults said that they received at least a portion of their income in 2007 from social assistance. Despite the prevalence of social assistance and related programs in Mi'kmaq communities, and in First Nations communities in Canada more generally, little research has been carried out on the subject. One of the only significant histories of welfare among Indigenous people in Canada noted, "there is an abundant literature on issues related to Indian self-government, health, land claims, economies and education, yet there is scarcely any on Indian welfare" (Shewell, 2004, p. 3). This article, drawing on federal and provincial archival sources, contributes to the task of understanding the historical roots of social assistance policy through situating its origins in the colonial destruction of the Mi'kmaw Indigenous economy. In doing so, we aim to contribute to contemporary Mi'kmaw struggles to establish sovereignty over social assistance. The history of failure in the realm of social policy discussed here and continuing struggles over its governance, we argue, shows that it is beyond time to change social assistance policy in Mi'kmaq communities.

Social assistance programs, as we think of them today, "provide financial assistance and in-kind goods and services to cover the cost of basic living requirements for an individual or family when all other financial resources of that individual or family have been exhausted" (Federal-Provincial-Territorial Directors of Income Support, 2016, p. 6). The jurisdictional organization of such programs in Canada is complicated. Under the Constitution Act, 1867, social assistance is a provincial responsibility. As a legacy of the Indian Act, 1876, however, First Nations living on reserve receive last-resort support from the federal government. This study's impetus lies in the federal government's attempt to have social assistance policy on reserves exactly mirror monetary rates that are used in the provinces. Mi'kmaq leadership have rejected this push (Simon v. Canada, 2012), arguing that, given the distinctiveness of reserve communities, it is both situationally and culturally inappropriate. Current Federal Provisions, for example, though far from ideal, allow for higher spending on housing and utilities than provincial rates would allow. Special consideration for Elders and children is also possible, a situation ineligible under provincial policy. In response to proposed changes, Mi'kmaq leadership, led by the Mi'kmaq Rights Initiative (Kwilmu'kw Maw-klusuaqn) in Nova Scotia (Hanrahan, 2016), has embarked on a path to negotiating a sectoral (self-government) agreement in the social policy area allowing greater control and design of policy. This article seeks to contribute to that process through detailing how the need for social assistance policy on reserve has emerged historically and why historical failures indicate a new path forward is necessary.

The administration of social assistance programs is further complicated by the various names that have been given to it, depending on jurisdiction and time period. What we now call social assistance has also been called different things historically. In the early years of contact with settlers in Nova Scotia, for example, in the context of Treaties of Peace and Friendship, assistance was part of a diplomatic exchange

\footnotetext{
${ }^{1}$ Here, our preferred usage is Mi'kmaq. Settlers have referred to them in many ways, including Micmac. In Canada, there are three major groups of Indigenous Peoples: First Nations, Métis, and Inuit. Mi'kmaq are First Nations. First Nations are also referred to as Indians.
} 
relationship and took the form of presents or gifts (Wicken, 2002). Subsequently, terms such as charity, relief, rations, and welfare were used as the relationship between the Mi'kmaq and European colonists changed. While we know something of the history of such policies in early-colonial Nova Scotia (Upton, $1973,1975)$, very little has been written about the post-Confederation period. This article begins to address that gap through detailing the historical production of economic dependence among the $\mathrm{Mi}^{\prime} \mathrm{kmaq}^{2}$ in Nova Scotia and the role that social assistance played in this process.

The changing name of social assistance leads to an important question regarding its role in Mi'kmaw livelihoods: How has the need for social assistance emerged historically? This is an important question because framing social assistance as a historical relationship places its development within a set of economic conditions and emphasizes the broader context of values, assumptions, and perspectives that underlie and shape the policy area.

\section{Social Assistance Policy’s Origins: Dependence and Dependency Theory}

Much research on the origins of social assistance policy focuses on how European industrialization created mass social upheaval resulting in, first, charitable organizations and, later, State support for "those people who were falling through the cracks of the rapidly proletarianizing society" (Fortier \& Hon-Sing Wong, 2019, p. 437). The origins of social assistance in Canada are rooted, of course, in Anglo-American industrialization and were a response to the harsh conditions and poverty faced by many settlers in the North American colonies (Ives et al., 2020). That story, though, is a partial one.

A growing body of literature has begun to address the colonial histories of social welfare policy in Canada and beyond (Brownlie, 2003; Chapman \& Withers, 2019; Midgley, 1997; Shewell, 2004; Taylor-Neu et al., 2019). Fortier and Hon-Sing Wong (2019) claim that social assistance policy's origins can be traced to paternalistic and "civilizing" colonial relationships "imposed on Indigenous peoples by early traders and missionaries long before the mass migrations of white settler populations at the dawn of the long nineteenth century" (p. 438). Contemporary social service provision, they argue, remains "circumscribed by logics of conquest, extraction, apprehension, management, and pacification that advance the settler project and seek to secure settler futurity" (p. 437). Scholars have also shown how Indigenous people have been characterized as dependent, lazy, and non-working. Such stereotypical descriptions have been central to the historical logic of social welfare policy through which "the lazy Indian” (Lutz, 2008) became an object of policy intervention and colonial control (Monaghan, 2013; O' Connell, 2013). Social assistance policy, both present and past, then, is inextricably linked to the history of settler colonialism in Canada. Nova Scotia is no exception.

Public and academic debates surrounding Indigenous livelihoods and the origins and functions of social assistance have frequently centred on the contested significance of the term "dependence." Many communities economically rely on social assistance to supplement their income. That relationship has been framed, in various ways, as one of economic dependence (Alfred, 2009; Helin, 2006). The condition of dependence, meaning reliance on others, however, is often negatively perceived in relation to social assistance. For Indigenous communities in particular, the spectre of dependence has been used to stigmatize and discipline social assistance recipients and undermine Indigenous sovereignty (Alfred,

\footnotetext{
${ }^{2} \mathrm{Mi}$ 'kmaq is the plural form of the singular word Mi'kmaw. In addition to being a singular noun, the word Mi'kmaw is also used as an adjective. Historically, Mi'kmaq and Mi'kmaw were frequently written as Micmac by colonists.
} 
2009; Harell et al., 2014; Papillon, 2015). The question we address here, however, is how did this situation of economic dependence emerge? And what kind of relationship, precisely, does dependence suggest? To answer this question, we engage dependency theory as a means to frame the emergence of social assistance.

Global South scholars working on or in Latin America and Africa initially developed dependency theory in the 1960s. These theorists defined dependency as "a situation in which the economy of certain countries is conditioned by the development and expansion of another economy to which the former is subjected" (Santos, 1970, p. 231). Dependence in this reading also indicates reliance, but a reliance produced by uneven incorporation into the global capitalist economy, not by some primordial lack of development. As a general theoretical framework for inquiry, dependency theorists focus on the structure of asymmetrical economic forces and the social transformations that accompany themexternal control of economic activity, the lack of economic diversification, and the structural distortions that afflict societies in peripheral regions (Wallerstein, 2011a, 2011b). This focus on uneven geographic development was highly influential to scholars trying to understand the relationship between the socalled First World and the Third World in the context of both decolonization and the persistence of unequal political and economic relationships. At a subnational, regional scale, this work was also influential, including in Atlantic Canada where scholars tried to explain the region's underdevelopment relative to Canada's core industrial provinces (Sager, 1987). How can dependency theory help us understand the historical emergence of social assistance among the Mi'kmaq in Nova Scotia?

Some attempts have been made to apply dependency theory to Indigenous Peoples in North America (Wilkins, 1993). Such studies emphasize the importance of market relations and dispossession in undermining Indigenous economic systems. Historian Richard White (1988) has shown, for the Navajo, Choctaw, and Pawnee peoples, that "the collapse of their subsistence systems and their integration into world markets brought increasing reliance on the capitalist core, lack of economic choice, and profound changes within their societies" (p. xix). For White, the emergence of dependency was a complex process. Settler dominance was not solely achieved by force. Instead, market relations and the insidious logic of exchange took effect long before colonial military dominance had been established. Indigenous societies, like the Mi'kmaq, who had once easily been able to provide for themselves, saw their environmental, social, and economic structures deteriorate as trade relations deepened. Gradually, White shows, Indigenous Peoples "obtained clothing and other manufactured items as the result of various exchanges (first of goods and military services, later of labor and the land itself) whose terms and methods were not beyond their control" (p. xix). Increasingly, however, the impact of epidemics, growing European settlement, and land pressure, saw Indigenous Peoples lose power over the key issues of what was to be exchanged, and how it was to be received and used. This process subjected Indigenous Peoples to indebtedness, dispossession, expropriation, and extreme pressure to assimilate and disappear.

Dependency theory, then, brings a historical sensibility to the question of economic relations and social assistance. The emergence of social assistance programs, in this framework, can only be seen as the result of broader socio-economic forces - it is a situation that has been historically produced. However, one cannot simply read social assistance policy today from a uniform experience of colonization and integration into the global capitalist system. The Mi'kmaq and Choctaw experience of settler colonialism, for example, though parallel, were historically, geographically, and culturally distinct. Dependency resulted from "a complex interchange of environmental, economic, political, and cultural 
influences understandable only within specific histories" (White, 1988, p. xix). Below we trace the specific histories through which social assistance emerged. We do so to properly situate debates about the role of social assistance and its governance and to show that such policies have failed to pay close attention to the possibilities of Mi'kmaq sovereignty in social policy.

\section{Colonial Transformation}

Our discussion of colonial relief policy and later federal policy must necessarily begin with understanding how Mi'kmaw communities in Nova Scotia $\left(\mathrm{Mi}^{\prime} \mathrm{kmaqi}^{3}\right)$ provided for themselves. The Mi'kmaw economic cycle was based on a seasonal round that drew on a variety of land and marine resources. In the spring, the Mi'kmaq inhabited coastal villages where they typically remained until fall. Here they harvested marine food sources and gathered berries and groundnuts. Many of these resources were stored for winter usage (Gonzalez, 1981). In late fall and winter, the Mi'kmaq moved further inland to hunt beaver, otter, bear, moose, and caribou. While a generalized picture, contemporary sources all note the variety of resources and the coastal-inland pattern of movement. This seasonal use maximized resource availability and emphasized changing ecological conditions.

The social and cultural organization that developed in tandem with the region's resource base emphasized mutual assistance. Mi'kmaw economic activities were organized on a community or settlement basis (Wicken, 2002). People lived in extended family groups and community leaders allocated hunting territories and resources (Wien, 1986). Community well-being was the overriding concern and extended families "ensured that each nuclear family could call on a sizable group of closely knit kin in the event of misfortune" (Miller, 1995, p. 356). In such a society, providing aid in times of stress was considered a communal responsibility. Early colonists such as Pierre Biard and Marc Lescarbot noted this social structure. Biard wrote that the Mi'kmaq shared everything: "No one would dare to refuse the request of another, nor to eat without giving him a part of what he has" (as cited in Paul, 2006, p. 34). Lescarbot (1928) spoke of Mi'kmaq society's "mutual charity," "hospitality," and acceptance of strangers in "their commonality of life" (p. 227). Others noted how "the support of widows and orphans was assumed by the best hunters" (Gonzalez, 1981, p. 15). A chain of benevolence and gratitude sustained this harmony and balance among living things. The sharing of gifts was also central to social relations, and it accompanied commercial and treaty arrangements. A person will share their home and goods with a visitor in need, who, in turn, would express gratitude by reciprocating inkind at a later date. Sharing was not just one relation among many; it was the basis of all relations. Mi'kmaq call this social support system Tpitnewey (Young et al., 2017).

These aspects of society were put under severe pressure by the arrival of Europeans in the $16^{\text {th }}$ century. One of the immediate consequences of extended contact with Europeans was deepening trade relations. The Mi'kmaq initially exchanged furs and handicrafts for Europeans tools, iron goods, and foodstuffs. The growing importance of furs, linked to an expanding European market, meant that opportunistic trading soon gave way to an organized fur trade. The fur trade's growth initially built on existing Mi'kmaq strengths - hunting, fishing, trapping, trading, and transportation. Despite their central role in the trade, Mi'kmaw traditional economic activities were gradually undermined as they became entangled

\footnotetext{
${ }^{3}$ Mi'kmaq Traditional Territory included Nova Scotia, Prince Edward Island, the Gaspé Peninsula of Quebec, the north shore of New Brunswick and inland to the Saint John River watershed, eastern Maine, and part of Newfoundland, including the islands in the Gulf of Saint Lawrence as well as St. Pierre and Miquelon.
} 
in the European-based market system. One of the central changes of this period stemmed from the transformation of hunting and production: from subsistence and socially oriented activities to activities carried out with the goal of market exchange. The fur trade exposed the Mi'kmaq to market vulnerability. In addition, the demand for furs and more destructive hunting technologies seriously depleted animal stocks. As the fur trade expanded, the Mi'kmaq altered their seasonal cycle in response to its demands (Gonzalez, 1982). A longer period of the year was spent hunting in the interior and, consequently, less time in the summer was available to support traditional coastal subsistence activities. The effects were wide ranging, transforming Mi'kmaq diets, clothing, settlement patterns, belief systems, and divisions of labour (Hornborg, 2016). ${ }^{4}$ Thus, while the fur trade offered some opportunities for the Mi'kmaq, allowing them to maintain much independence (Reid, 2004), it also posed significant problems as it undermined Mi'kmaq self-sufficiency. Its decline, however, was catastrophic.

In the late decades of the $18^{\text {th }}$ century, numerous changes occurred that further altered Mi'kmaq livelihoods. The British defeat of the French in North America in the 1750s meant the Mi'kmaq lost a valuable political ally and a strategic position as intermediaries. Two decades later, the U.S. War of Independence saw an influx of settlers from the south, while migration also increased from Europe (Reid, 2009). The new settlers took the best lands for agriculture, fishing, and lumber, placing increased pressure on resources. These activities replaced the declining fur trade. The Mi'kmaq, as a result, largely became regarded as an obstacle to settlement. In effect, they lost their economic and strategic value as traders and warriors. Colonial policy now explicitly viewed them as a social problem. Pre-colonial livelihoods, already threatened, were now under severe pressure.

There are many indications that Mi'kmaq life was under siege. Analyses of Mi'kmaq population, for example, suggest that there was a decline from 26,000 in the pre-contact period to 10,000 by 1761 (Miller, 1976). By 1849, Mi'kmaq Chiefs claimed that "the whole of our people in Nova Scotia is about 1,500" (Gonzalez, 1981, p. 81). The dramatic transformations of the previous centuries threatened Mi'kmaq survival. In this era of scarcity, the colonial government began to issue small amounts of supplies, called relief, to destitute Mi'kmaw families. Relief in the form of occasional grants of blankets, potatoes, shot, and other necessities acquired newfound importance. There is reason to believe that, as opportunities for trade declined, the Mi'kmaq "returned to some extent to the more balanced and seasonably varied subsistence pattern that characterized aboriginal times" (Wien, 1986, p. 10). However, the topography of Mi'kmaq livelihoods had changed dramatically. The Mi'kmaq had already begun to incorporate gift-giving, fur trading, and farming into their seasonal rounds by the $18^{\text {th }}$ century (Wicken, 1991). European colonization had, thus, permanently altered the economic conditions under which the Mi'kmaq could remain self-reliant. As a result, selective engagement with changing economic opportunities became a key aspect of Mi'kmaq survival.

\section{Agriculture and Colonial Policy}

In 1768, Britain gave responsibility for local affairs, including the Mi'kmaq, to Nova Scotia's colonial government. Local control, however, did little to focus more attention on the Mi'kmaq's needs. Amongst occasional grants of relief to those in dire need, a pattern began to emerge that would endure for much of

\footnotetext{
${ }^{4}$ These transformations also had a gendered aspect to them. Gonzalez (1982) argued that by 1850 the combined impact of Western technology, religion, and new economic activities undermined the Mi'kmaq's traditionally “interdependent” gender relations. Parnaby (2011) dated "the onset of female economic subordination" to the late 1800s (p. 24).
} 
the $19^{\text {th }}$ century. In summer, Mi'kmaq families would camp near a village to sell their handcrafts and wares. In winter, the people would return to the forest to hunt. If game was exhausted, they would remain near the village seeking relief as part of settler communities' responsibilities to the "indigent poor" (Upton, 1975). The classification of the Mi'kmaq as "indigent poor" was frowned upon by parsimonious legislators who were reluctant to provide relief to the Mi'kmaq at the colony's expense.

Initial ad hoc policies aimed at addressing Mi'kmaq problems focused on promoting agriculture, rather than granting relief, which, colonial administrators argued, only intensified "the worst traits of the Indian character, indolence and drunkenness" (Sargent et al., 1800, p. 3). Agriculture, it was argued, would promote self-reliance, a claim that would have a long life in colonial policies imposed on the Mi'kmaq (Haigh, 2000; Mrazek, 2017). This reluctance to systematically aid the Mi'kmaq saw the Nova Scotia Assembly vote to allocate a mere $£ 350$ for relief in 1800 . After sending blankets, powder, shot, and potatoes to the First Nations near Lake Antigonish, the committee stated: "It will be in vain to look to the government for annual support ... they shall cultivate the ground, otherwise they will be abandoned to their fate" (Sargent et al., 1800, p. 3). After 1800, a piecemeal approach emerged where lands were occasionally set aside for the Mi'kmaq, a practice which set a precedent for the establishment of a formal reserve system. In 1820, for example, parcels of land were set aside for settlement but a combination of a lack of funding, training, implements, and encroachment by Whites saw even this paltry attempt at alleviating Mi'kmaq poverty fall short. However, "faced with either starvation or the possibility of receiving some meagre relief on these lands, some of the Indians were drawn to the designated areas" (Patterson, 1985, p. 14). Neither agriculture nor sporadic relief funding, however, were sufficient for dealing with the perennial subsistence crises facing the Mi'kmaq.

By 1827, Mi'kmaq destitution placed the colonial government under enough humanitarian pressure to compel annual grants for relief. An 1841 petition to Queen Victoria by Chief Louis Benjamin Peminuit Paul outlined the continuing crisis: "My people are poor. No hunting grounds-No beaver-No Otter-no nothing ... White Man has taken all that was ours" (as cited in Whitehead, 1991, p. 219). On receipt of the petition, the Colonial Office in London demanded action from Nova Scotia's new Lieutenant Governor, Lord Falkland, who in 1842 passed an Act for the Instruction and Permanent Settlement of Indians. This Act gave rise to the formal reserve system that would dramatically alter Mi'kmaw life. To implement the Act, Joseph Howe was appointed Indian commissioner for Nova Scotia in 1843 . Howe subsequently launched an investigation into previous attempts to aid the Mi'kmaq. Of the 20,050 acres set aside as reserves, he reported, the majority were "sterile and comparatively valueless," and where there was valuable land, its quantity had been "diminished by the encroachment of the whites" (Howe, 1843, p. 5). Though the colonial government had been charged with providing permanent lands for settlement, reserve land was rarely protected from the continued invasion of colonists. Thus, though agriculture had been presented as a long-term solution for demands for relief, that solution was proscribed by settler colonial thirst for land.

Howe (1843) indirectly linked continuing Mi'kmaw dispossession to growing demands for relief. In spring, he wrote, his home "was besieged, at all hours, by Indians, who had been taught to believe that unbounded wealth was at my disposal, and that they were to be fed and clothed hereafter at the expense of the Government" (p. 3). From its earliest days, the spectre of dependency haunted Indian policy in Nova Scotia. In response to these claims, Howe (1843) clarified relief s governing principle: "The rule I adopted, was to give relief only to the old and infirm, the sick or maimed, or to those who had met with 
some calamity" (p. 4). Relief could only be granted in exceptional circumstances. As the report itself shows, however, the majority of the Mi'kmaq were already living in such exceptional circumstances.

An 1849 petition from Mi'kmaq Chiefs noted that their position had worsened after the potato blights of 1846 and 1848. Without access to game, fishing, and a market for their products, their nation, the Chiefs remarked was "like a withering leaf in the summer sun" (Whitehead, 1991, p. 239). The requested help to pursue the government's proposed agricultural policy was, predictably, not forthcoming. In fact, one of Howe's successors, William Chernley, abandoned the settlement plan in 1853, concluding that, "since the Mi'kmaq were 'fast passing away,' the most that could be done was to ease their last days by providing whatever relief the province would allow them" (as cited in Patterson, 1985, p. 15). The Mi'kmaq continued to eke out a living by adapting previous economic patterns, but every year returned to a lower level of subsistence. Agriculture, it seems, was never considered a viable solution to Mi'kmaq poverty. Instead, farming and the reserve system was used to expropriate and confine the Mi'kmaq to marginal lands, justify limited relief payments, limit mobility, and to facilitate monitoring and control.

\section{Post-Confederation and the Provision of Relief}

From the post-Confederation period through to World War II, two broad processes greatly impacted Mi'kmaq livelihoods: Confederation, including the federal assumption of responsibility for Indian Affairs, and industrial developments in Nova Scotia. Together these processes transformed Mi'kmaq life. Though generally economic and administrative developments are treated in isolation, the links between them are crucial. It was here at the intersections between independent production, wage labour, and the long arm of the federal state that modern social assistance policy emerged. At the same time, as the federal government sought to transform the Mi'kmaq into wards of the state, the Mi'kmaq began to establish themselves in an industrializing settler economy. Thus, despite increasing state intervention and the expanding apparatus of the Department of Indian Affairs, the Mi'kmaq retained much independence. ${ }^{5}$ The Great Depression and centralization policy in the 1940s dramatically undermined that independence, when the "hegemony of the Canadian state" reduced many Mi'kmaq to wards of the Crown and "systematically denied First Nations their inherent capacities to develop solutions to their own problems” (Shewell \& Spagnut, 2002, p. 41).

Confederation transferred jurisdiction of Indian Affairs from Nova Scotia to the new federal government (Shewell, 2004). Early directives reaffirmed the colonial status quo: The Mi'kmaq were expected to be self-sufficient, growing, where possible, their own food. Indian agents were tasked with maintaining this situation by monitoring each reserve's affairs and revenue, documenting its activities, encouraging agriculture, and granting relief to those in great distress. This state of affairs would remain in place until the Second World War. In most cases, relief was an isolated response to hardships caused by food shortages, disease, and harsh winter conditions. Despite its importance, however, there was no statutory provision for relief expenditure. The Indian Act was silent on the subject of the provision of essential

\footnotetext{
5 The Department of Indian Affairs, established as a separate administration in 1880, has undergone numerous transformations over the past 140 years. It has been part of various government departments: The Interior (1873-1880), Indian Affairs (1880-1936), Mines and Resources (1936-1950), Citizenship and Immigration (1950-1965), Indian Affairs and Northern Development (1966-2017), and, most recently, Indigenous Services Canada. We refer to it here as the Department of Indian Affairs, the most common usage during the period under examination.
} 
services on reserve. As a result, relief policy was essentially laissez-faire, subject to frequent change and arbitrary decisions.

Mi'kmaw economic precarity was compounded by the ups and downs of the settler economy. Nova Scotia suffered during the economic Depression that swept the U.S. and Canada from 1895 to 1896. As was often the case with ecological and economic crises since colonization, the Mi'kmaq were disproportionately affected. Deputy Superintendent General Hayter Reed (1895) reported that the Depression "affected not only the whites but also the markets of the Indians in the sale of produce, and manufactures and labour in various directions" (p. 39). In response to these economic difficulties, the government reduced relief spending across the provinces. In 1896, Indian agents in Nova Scotia actually spent less than their allotted budget. Out of \$2,500 allocated to relief and seed distribution, \$453 went unused (Government of Canada, 1896, p. 748). For those who relied on relief, such tight accounting could walk the fine line between survival and starvation.

Most Department of Indian Affairs administrators saw relief as a form of charity necessitated by the perceived Mi'kmaq inability to modernize and become farmers, and to their supposed "indifference about the future" (Spragge, 1873, p. 8). As the Mi'kmaq continued to resist colonialism's onslaught, and were clearly not vanishing as predicted, the Department of Indian Affairs still hoped that they could be "transformed into something approaching white settlers by reshaping, controlling, and managing their environments” (Bednasek \& Godlewska, 2009, p. 444). In contrast to agriculture's settled nature, mobility was still seen as a persistent problem to agents' civilizing mission. In 1876, the agent at Grand Narrows reported that, instead of farming, the Mi'kmaq "prefer to be migrating, with quivering muscles, from one place to another, begging their livelihood" (McGillivray, 1876, p. 131). A wide range of reports reinforced the idea that Indigenous people experienced poverty because of their "indolence" and predisposition to mobility (Ellingson, 2001), a strategy that sought to delegitimize the historical and contemporary importance of migratory movement to Indigenous political and economic autonomy (Howard-Wagner \& Kelly, 2011). Despite such attempts to fix the Mi'kmaq in place, they continued to leverage mobility as a key economic strategy.

\section{Mi'kmaq Resilience in an Industrializing Economy}

The $19^{\text {th }}$ century could be characterized by the dramatic aftereffects of the decline of the fur trade, growing European settlement, the emergence of the reserve system, and the failure of agricultural policy. In the late 1800s and early 1900s, however, the "neat" story of the inevitable Mi'kmaq decline and disappearance told by Indian agents was arrested. Part of this recovery lay in strategic Mi'kmaq participation in broader economic developments in Nova Scotia. Between 1870 and 1910, Nova Scotia's economy industrialized rapidly (Alexander, 1978; Inwood, 1991; Samson, 2008). Emerging industrialization created coal, iron, and steel sectors whose development, though vulnerable to periodic global downturns, created expanding opportunities for wage labour. As a result, the Nova Scotian labour force underwent dramatic sectoral shifts. Agriculture, hunting, and fishing, which made up $75 \%$ of the labour force in 1871 , declined to $20 \%$ by 1940 (Wien, 1986). Nova Scotia transitioned from an agricultural economy to an industrial economy, and the Mi'kmaq joined this industrial labour force. As early as 1882, we see reports of Mi'kmaq men engaged in summer work in lobster factories, sawmills, and rafting lumber. McDonald (1884) commented that in response to "the disappearance of forest" and its "ancient occupation," the Mi'kmaq became farmers, miners, shipwrights, and carpenters: "There is no 
employment in which he does not compete, occasionally at least with his white brethren" (p. 141). They engaged in a broad range of labour activities, which contributed to growing economic stability. By 1905, one agent reported that "some of them are quite independent and do not require any assistance; nor would they thank any one for offering them charity" (Fraser, 1905, p. 149). Expanding economic opportunities allowed the Mi'kmaq to begin to rebuild their economic base in a way that agricultural policy and confinement to reserve never had.

Wage earning became a significant part of Mi'kmaq subsistence strategies, a fact reflected in its inclusion as a category in Indian agents' reports to the Department of Indian Affairs. In 1920, annual reported wages earned by the Mi'kmaq in Nova Scotia were valued at $\$ 83,380$, which is half of their estimated total income (Government of Canada, 1920, p. 72). During the remainder of the 1920s, wages declined slightly to hover around the $\$ 60,000$ mark. Occasional spikes in relief corresponded with economic downturns, showing that relief was not a consistent problem when employment was available. Changes in wages earned, however, also reflected Mi'kmaq choices regarding employment. In 1908, the Department of Indian Affairs observed that engagement in wage labour fluctuated "in sympathy with the condition of their other available industries, and increased activity in their direction becomes apparent if husbandry, or hunting, fishing or trapping for any reason decline” (Pedley, 1908, p. 41). Steven High (1996) argued that First Nations' participation in the Canadian economy occurred selectively to strengthen their traditional way of life. Wage labour was part of a wide range of economic activities and must "be seen in relation to the resiliency of aboriginal societies" (p. 263). During this period, Indigenous labour participation was rapidly growing across Canada. The Department of Indian Affairs noted in 1911 that across Canada it was "worthy of attention from economists that the Indian is a sufficient factor in the labour market to account for a million and a half dollars annually" (Pedley, 1911, p. 44). The Mi'kmaq were part of this broader Canadian pattern.

The Mi'kmaq diversified their economic base. Traditional hunting and fishing continued but were limited. Colonial administration encouraged livelihoods such as farming and coopering, which became part of their survival strategies. The Mi'kmaq developed a range of other activities. They became guides in the burgeoning tourism industry, worked as migrant labourers in agriculture, and Mi'kmaq women continued the practice of making baskets and handicrafts. Mi'kmaq economic activities, as they emerged in the late $19^{\text {th }}$ and early $20^{\text {th }}$ centuries, were a complex combination of government subsidized work projects, wage labour, "and activities that combined indigenous knowledge and skills with market demand” (Gonzalez, 1981, p. 65). Through mobility and economic adaptation, they retained a sense of autonomy. Despite continual government pressure "they eschewed the stark set of choices laid out for them by the colonial (and later federal state) and European settlers-opting instead to farm, utilize their 'customs,' and serve their 'maker' at one and the same time" (Parnaby, 2008, p. 96). The Mi'kmaq participated in a wide range of economic activities that ensured their nation's survival in changing economic circumstances.

Why have these developments in Mi'kmaq economic activities received such little attention? The answer partly lies, we argue, in a reluctance to see the Mi'kmaq as active economic agents. The Mi'kmaq, like other First Nations, were perceived as a people outside of history-traditional, static, and unchangeable. Many agents approached their work through this framework of the "timeless Indian," which, according to one, "live from hand to mouth, are happy, and contented, and die with visions of blissful immortality - the happy Indians" (MacLeod, 1906, p. 139). Such statements reinforced the view of the 
primitive Indian, a remnant of the past intruding on the modern world. The government's policy of assimilation and protection also framed them as a people outside of mainstream society and, thus, outside of the economy.

The orthodox economic view of modernization argued that modern life had passed the Mi'kmaq by. Anthropologist Diamond Jenness (1932/1977), for example, suggested that First Nations lagged behind the march of progress. "Socially," he wrote, "they are outcasts, economically they are inefficient and an encumbrance" (p. 350). This static view vigorously opposed the idea that First Nations exercised agency over their economic lives. One of the aims of such discourses was "the disabling of indigenous agency" in order to narrow the domains in which Indigenous Peoples could exercise agency (Neu \& Graham, 2006, p. 73). Denying the Mi'kmaq agency rationalized the government's paternal attitudes and control of Indigenous affairs. This deliberate oversight of Mi'kmaq agency matters, because by the end of this period in 1933, economic dependency was perceived as a permanently defining feature.

Framing the Mi'kmaq as outside modern society and the economy was crucial to obscuring their economic agency. When their economic engagement has been grudgingly acknowledged, that participation has been seen as an indication of their abandonment of a traditional way of life (Haddad \& Spivey, 1992; High, 1996). Wage labour, in this sense, has been perceived to function as an instrument of assimilation, like property ownership: a symbol of acceptance of Western society and values. Various scholars question this reading, arguing that while Indigenous agency has been "virtually undisputed in studies of the fur trade, little agency has been granted to those who participate in the later industrial economy" (High, 1996, p. 249). Contrary to the traditional view of the period, First Nations, including the Mi'kmaq, did indeed participate in wage labour. The continued preference of First Nations for casual work, however, "resulted in their own status being diminished, thereby generating the stereotype of the 'shiftless' and 'undependable' Indian” (High, 1996, p. 253). Casual work was pursued, nonetheless, because it allowed independent production to continue its central role in Mi'kmaq life. Thus, participation in wage labour and self-employment, or other off-reserve employment, did not represent an abandonment of traditional life. Rather, it was a selective and complex adjustment to structural economic change and a form of resistance to an overbearing colonial administration. Paying attention to Mi'kmaq wage labour is crucial as it undermines the popular version of economic dependence as a timeless condition, and repositions it, according to dependency theory, as the result of a series of historical and structural changes in settler-Mi'kmaq relations.

\section{The Great Depression and Social Assistance}

Beginning in the 1920s, the Nova Scotian industrial economy began to decline (Inwood, 1991). As in previous periods of broader economic hardship, the Mi'kmaq were affected, and relief payments began to slowly increase (Figure 1). Economic circumstances were clearly central to rising relief payments to the Mi'kmaq. However, a large part of it was also due to increases in medical spending, a growing Mi'kmaq population, and the broader expansion of modern welfare services. In short, social welfare for both Indigenous Peoples and settlers expanded concurrently with industrialization (Fortier \& Hon-Sing Wong, 2019). Despite the growing remit of governments to provide basic services in periods of hardship, the Department of Indian Affairs resisted this expansion and continued to blame rising expenditures on Mi'kmaq dependence. 
By 1918, Indian Affairs saw relief dependence as an entrenched problem in Nova Scotia. The Department of Indian Affairs, preoccupied with Treasury directives regarding Canada's World War I debt and public spending, went on the offensive. Ottawa advised agents "to keep spending down to the lowest possible amount without inflicting suffering” (Shewell, 2004, p. 107). The Department of Indian Affairs began to cancel relief during summer months. Rising unemployment replaced relative prosperity during the 1920s, which led to a "downward spiral in Indian welfare and neglect" (Shewell, 2004, p.

108). This general decline was dramatically punctuated by the Great Depression, which was a catastrophic event for the Mi'kmaq of Nova Scotia.

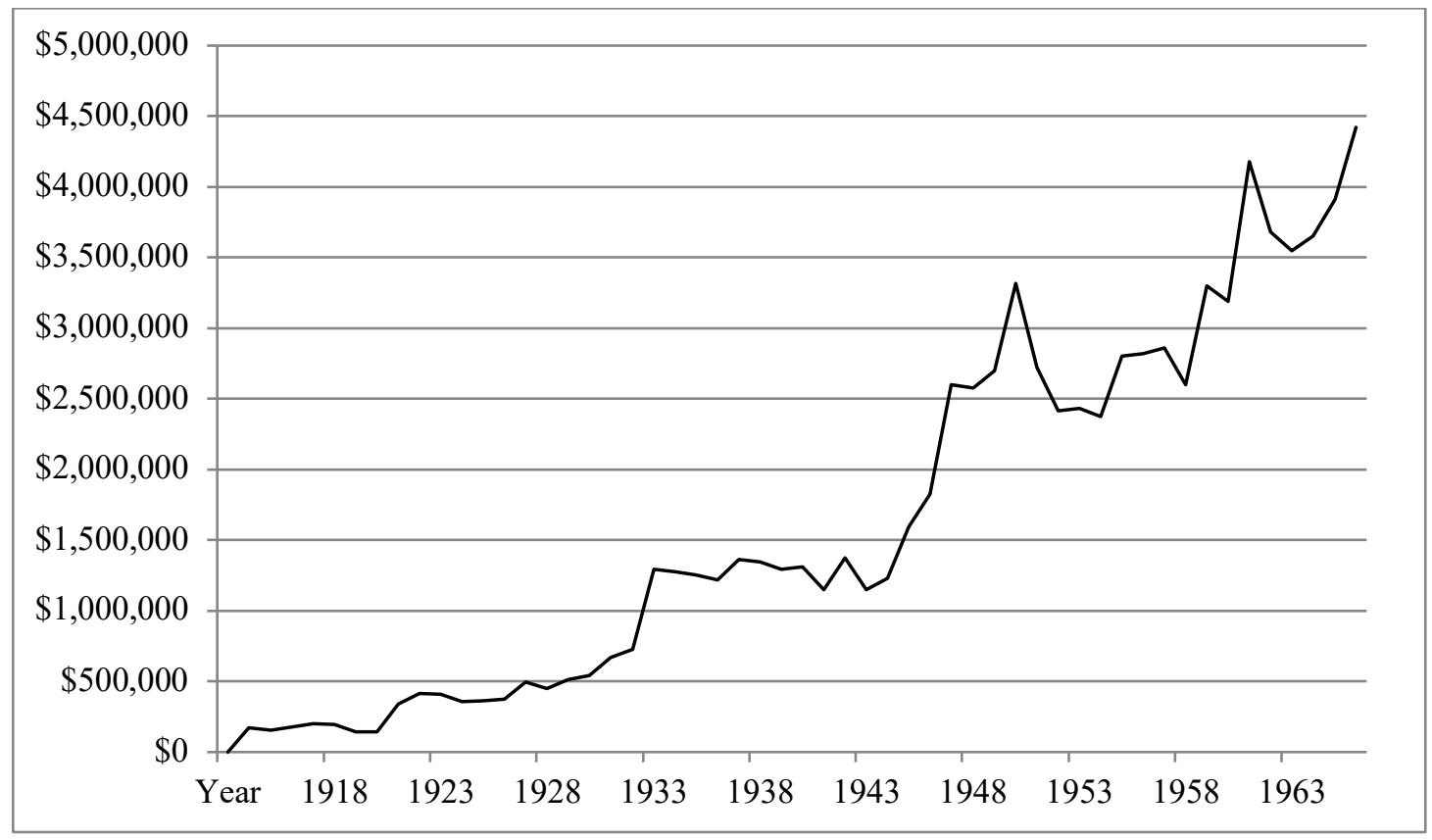

Figure 1. Department of Indian Affairs Relief Spending in Nova Scotia, 1914-1966. Adjusted for inflation. Source: compiled from Library and Archives Canada, RG10, Indian Affairs Annual Reports, 1864-1990.

Extremely low commodity prices greatly affected the majority of the industries where the Mi'kmaq had previously found employment. Labouring at the margins of the economy, they were "traditionally the last hired and the first fired" (Forbes, 1993, p. 275). The hard-fought economic stability won by many Mi'kmaq communities remained precarious and the elimination of wage labour income caused severe hardship. By 1934, according to the Department of Indian Affairs "virtually every Indian in the province [was] on relief." Adjusted for inflation, relief spending almost tripled from $\$ 448,364$ in 1928, to $\$ 1,293,501$ in 1933 (Figure 1). Deputy Superintendent Harold McGill (1934) outlined the severity of the situation: 
It is feared that the re-employment of Indian industrial workers laid off due to the Depression will be slow as in this field naturally unemployed whites have the preference in most communities and the Indians are at the end of the line. In the Maritime Provinces, where Indians in the past relied upon employment in the lumber camps, the sale of native wares and odd jobs, they are in more straitened circumstances than in other Indian communities in the Dominion. (p. 8)

Racialized hiring practices dictated that the Mi'kmaq suffered more than their White counterparts. Certainly, First Nations in Canada were disproportionately unemployed in the 1930s compared to the settler population. To make matters worse, relief scales for First Nations were actually reduced during the Great Depression, leading to greater suffering and neglect. In 1936, 20\% of the Canadian settler population was on relief, compared with $33 \%$ of First Nations. In addition, per capita relief expenditures in 1936 were $\$ 61.69$ for the Canadian settler population and just $\$ 20.57$ for First Nations (Shewell, 2004, p. 123). Furthermore, it appeared that some employers felt that it was not necessary to re-employ the Mi'kmaq.

As wards of the federal state, there seems to have been the belief among settlers that the Department of Indian Affairs would take care of First Nations people. An unsigned inspector's report regarding the situation in Nova Scotia in 1933 confirmed the prevalence of this belief, writing: "The whole attitude of the white population is, why bother with the Indians, the Government is obliged to look after them" (Department of Indian Affairs, 1933, p. 2). Under these dire economic circumstances, relief became a necessity in most Mi'kmaq communities. This development was an unwelcome one for the Department. The Department of Indian Affairs Inspector claimed that the "genesis" of the relief problem was misplaced paternalism and the Mi'kmaq ability to exploit government resources. Thus, he remarked, Indians were given free health care education, freedom from taxation, and reserves and once these had been provided "gratis," food, clothing, and housing were expected. The federal government's response to the erosion of Mi'kmaq livelihoods was swift, misplaced, and guided by deep desire to reduce budget expenses. Ultimately, the Department of Indian Affairs' plan to permanently reduce expenditure on the Mi'kmaq of Nova Scotia proved catastrophic and dramatically expanded the reach of the welfare state into Mi'kmaw lives.

\section{Centralization}

The Depression placed relief at the very forefront of the Department of Indian Affairs' concerns. The majority of correspondence from this period focuses on varied solutions to "the relief problem, which [had] grown beyond all reason and threaten [ed] to spread its tentacles if not subjected to immediate action" (Department of Indian Affairs, 1933, p. 1). As relief spending continued to rise, officials began to revisit the idea of centralizing the 45 reserves in Nova Scotia. Rather than attempt to help the Mi'kmaq gain re-entry into the workforce and rebuild their economic base, the Department engaged in a dramatic and ambitious social engineering project: centralization.

The amalgamation of reserves had been subject to discussion for at least two decades. A small precedent was set in 1918 when 15 families of the Halifax Band were moved to the Millbrook reserve after the Halifax explosion. A flurry of letters in the 1920s advocated creating a systematic policy for centralizing reserve populations. Dr. H. S. Trefry (1924) suggested the Department sell the province's scattered 
reserves and find "a good situation of fertile Crown Land, and collect all the Indians to it" (p. 2). Central reserves, he argued, were the only solution to "deplorable" conditions and considerable government spending with little result. Ottawa assured Trefry they would consider the problem carefully but that currently there was no solution as the Mi'kmaq "appear to prefer their current mode of life and resent any form of paternalism, which might tend to restrict their liberty or repress their nomadic instincts" (Campbell-Scott, 1925, p. 1). The Mi'kmaq, it seemed, were reluctant to give up their hard-won economic independence and surrender their mobility, which was historically a key economic coping strategy

The idea of centralization continued to gather pace in the 1920s and 1930s as persistent reports normalized its logic. Indian Agent and Crown Timber Officer H. J. Bury's (1925) report on "the Indian Situation in Nova Scotia" advocated amalgamation of reserves in three central locations, a process that would be paid for by the sale of all other reserves. Bury also detailed the cost effectiveness and the moral and material benefits of having a full-time agent on reserve. In 1936, a specially commissioned report by Departmental expert Dr. Thomas Robertson (1936) argued that the Mi'kmaq were "deteriorating and looking more and more to the government for his support" (p. 10). Robertson suggested amalgamating reserves and that "direct relief be discontinued and all able required to work for anything received" (p. 11). Centralization, thus, was conceived as a direct response to increasing relief expenditure.

While centralization was debated, the Department sought to restrain daily spending by decreasing relief rates. Frequent changes occurred in relief rates to help foster organizational efficiency and fiscal control. These experiments occurred in response to rising expenditure and "established a new level of rationalized relief administration that would eventually apply throughout the country and that would make First Nations even more concentrated 'objects' of bureaucratic oppression" (Shewell, 2004, p. 121). In 1940, in an attempt to curb spending, the Department issued a circular specifying the scale of monthly allowance to its agents and cutting numerous items. Milk, eggs, tinned tomatoes, root vegetables, and apples could not be distributed without Ottawa's authority (Shewell, 2004). These items, Indigenous communities were informed, could be grown. Lisa Patterson noted that at the heart of centralization policy lay "an almost pathological fear of large expenditure" (Patterson, 1985, p. 1). As expenditure on the Mi'kmaq in education, healthcare, and relief increased persistently, it was thought that combining these costs and geographically centralizing them might solve the problems created by Nova Scotia's economic downturn.

Finally, in 1941, the Department of Indian Affairs commissioned a report by W. S. Arneil into Indian reserves in Nova Scotia. His report was the tipping point in a 20 -year process. The federal government decided to centralize all reserve communities at two locations: Shubenacadie in mainland Nova Scotia, and Eskasoni in Cape Breton. Arneil recommended that the Mi'kmaq who were not receiving relief be allowed to stay on their present holdings and be encouraged to seek enfranchisement (Arneil, 1941). The goal was clear. If proper supervision, education, and health care could be administered on reserves, it would make it easier for the Mi'kmaq to join Canadian society, though at a later date.

The Mi'kmaq were not consulted about the drastic changes to their life and rightful territories. Some resisted, choosing to stay where they were (Hanrahan, 2008). Many moved, swayed by promises of homes, schools, jobs, and new services. Others were forced into moving by the actual termination of services at their reserves. Elders recall how smaller communities, such as Malagawatch, Port Hood, and 
Tufts Cove, experienced dramatic losses in population. The Mi'kmaq also recall the homes and communities they left behind being destroyed by Indian agents (Young et al., 2017). Some of the more profitable and self-sufficient Cape Breton reserves were also emptied. As a consequence, gains in agricultural development were lost, and those who had made successful economic adaptations to life at their small reserves were uprooted. In addition, in the new locations, traditional activities like hunting and trapping declined because of a lack of game, fishing became difficult because of overcrowding, and the sale of handcrafts also declined due to the lack of access to markets. The promised benefits of centralization also failed to materialize. The reserves were plagued by mismanagement, and a lack of materials, roads, and steady employment. Mi'kmaw ability to rebound from the economic deprivations of the 1930s was severely obstructed.

Arguably, centralization "affected Indian life in the province more than any other post-Confederation event; today its social, economic, and political effects are still felt" (Patterson, 1985, p. 1). The effects were legion. For example, Elders interviewed generally agreed that centralization devalued Mi'kmaw spiritual life "by depriving them of the work and social interactions they previously enjoyed" (Patterson, 1985, p. 114). Others noted that community feeling was destroyed by tension and competition between newcomers and original reserve residents. Self-sufficiency and pride in economic independence was also eroded by the new workfare regime on reserve. Many noted conditions at Eskasoni reserve on Cape Breton Island were worse than what they had left behind. Mi'kmaw Elder Victor Jeddore, for example, recounted how he abandoned a life built on fishing, hunting, agriculture, lumberjacking, and off-reserve work at Whycocomagh to move to Eskasoni (Patterson, 1985). Self-sufficient producers like Jeddore found themselves forced to work for welfare. The broader economic effects produced by isolation were just as problematic.

Long-term employment was difficult to generate for such large, concentrated, and isolated reserves. It seemed difficult to see where on-reserve employment would come from (Steen, 1951). Initially, Departmental reports showed that "wages earned" dramatically increased from $\$ 20,000$ in 1943 to a total of $\$ 98,500$ in 1946 , slightly higher than the estimated pre-Depression peak in 1920 . The vast majority of reported wages were earned in construction projects at the new reserves. Thus, the earnings reflected more of a work-for-welfare situation than sustainable long-term employment. This situation was confirmed by the discontinuation of the "wages earned" category in 1946. Earnings figures were simply folded into the larger category of welfare expenditure. Despite centralization's ostensible aim of reducing welfare expenditure, it continued to grow rapidly.

In 1949 centralization was declared a failure. At least $50 \%$ of the Mi'kmaq population had returned to their original reserves, where they attempted to pick up the pieces and re-establish some measure of economic stability. However, following centralization, unemployment continued its upward trend. Mi'kmaq accounts of this period confirm that centralization was a key factor in establishing the centrality of welfare in these communities. Furthermore, centralization eroded trust in the institutions of governance and administration. Promises of jobs, housing, and community development were not kept and several Elders mentioned that centralization did more to destroy the Mi'kmaw way of life than anything else (Young et al., 2017). At Eskasoni and Shubenacadie, unprecedented levels of social assistance were required to maintain their populations. Social deterioration characterized the 1950s such that by 1958, according to one account, approximately $98 \%$ of the households at Eskasoni and $78 \%$ of those at Shubenacadie were receiving welfare. Eskasoni was among the top 10 agencies in the country 
terms of welfare expenditure per capita (Hawthorn, 1966, p. 115). Elders interviewed in 1974 and 1975 argued that the failed centralization experiment had a significant impact on communities by eroding economic independence, circumscribing mobility, and necessitating dependence on social assistance payments (Patterson, 1985).

\section{Conclusion}

Mi'kmaq economic independence had been severely undermined by centralization, which precipitated the expansion of the post-war welfare state into Mi'kmaq communities. As the 1940s turned into the 1950 s and 1960s, Canada gradually put in place the universal social programs that are the hallmark of the modern welfare state- programs such as unemployment insurance, pensions of various kinds, social assistance, and universal health care. First Nation persons living on reserve were often not initially included, continuing to experience lower benefits and arbitrary administration as before. However, this changed as well and, by the mid-1960s, the Mi'kmaq living on reserve for the first time began to experience a stable and predictable income floor on more or less the same basis as other Canadians. Over time, divergences have again emerged. The provinces, for example, offer a much broader array of programs to supplement the income support that is provided. They also provide occasional increments to their social assistance rates, something that has not happened on reserve since the early 1990s. Indeed, Indigenous Services Canada itself states that the federal government's Income Assistance program "has not kept pace with renovations to provincial and territorial programming which offers similar programs" and that "a new approach, involving First Nations communities and service providers, is needed” (Government of Canada, 2014, para. 1). Such an approach must take into account the historical origins of social assistance policy outlined here and its failure to implement Mi'kmaq-led approaches to community well-being.

First Nations communities continued to suffer from a historical legacy of dispossession, displacement and assimilation, and federal policy choices that were at best misguided and at worst deeply damaging, such as implementing residential schools and centralization. In this and other ways, their experience was not unique. Stephen Cornell, one of the principals of the Harvard Project on American Indian Economic Development, puts this in a wider context, commenting on the individualizing effects of government policy. He notes that governments in the CANZUS countries (Canada, Australia, New Zealand, and the United States) see Indigenous people as a persistent policy problem. Governments address Indigenous issues by focusing on Indigenous persons, believing that if you address enough individuals then the collective problem will be solved.

I believe the approach is backwards. The collective, in fact-the nation, the community, the people, the tribe, whatever you call it - the collective is the heart of the matter. Invest in the aspirations and well-being of peoples and the well-being of individuals will follow. (Wien et al., 2018, p. 18)

A defining characteristic of social policy on reserve has been the fact that First Nations themselves have had very little say in how programs, such as social assistance, are designed and delivered. They have essentially been imposed from outside. For the Mi'kmaq in Nova Scotia, however, a door was opened in 2016 when a new government in Ottawa indicated it was prepared to consider a new approach to social assistance that is determined in large measure by the Mi'kmaq themselves. At the time of writing in the 
summer of 2020, design work supported by research was actively underway in preparation for negotiations to begin in the near future. There is hope that a more balanced, holistic, and selfdetermined approach will result. Our historical analysis shows that when the Mi'kmaq have been free to choose their own path, they have found their own solutions to the continuing challenges of economic development and colonial control.

\section{References}

Alexander, D. (1978). Economic growth in the Atlantic region, 1880 to 1940. Acadiensis, 8(1), 47-76.

Alfred, T. (2009). Colonialism and state dependency. Journal of Aboriginal Health, 5(2), 42-60.

Arneil, W. S. (1941). Investigative report on Indian reserves and Indian administration, province of Nova Scotia, Indian Affairs Branch. Department of Mines and Resources.

Bednasek, C. D., \& Godlewska, A. M. (2009). The influence of betterment discourses on Canadian Aboriginal Peoples in the late nineteenth and early twentieth centuries. The Canadian Geographer/Le Géographe canadien, 53(4), 444-461. https://doi.org/10.1111/j.1541$\underline{0064.2009 .00281 . x}$

Brownlie, R. (2003). A fatherly eye: Indian agents, government power, and Aboriginal resistance in Ontario, 1918-1939. University of Toronto Press. https://doi.org/10.3138/9781442659827

Bury, H. J. (1925). The Indian situation in the province of Nova Scotia as it exists at the present time. Library and Archives Canada (LAC. RG 10, Vol 3220. File - 536,764-1).

Campbell-Scott, D. (1925, February 3). [Letter to H.S. Trefry]. Library and Archives Canada (LAC. RG 10, Vol 3220. File - 536,764-1).

Chapman, C., \& Withers, A. J. (2019). A violent history of benevolence: Interlocking oppression in the moral economies of social working. University of Toronto Press. https://doi.org/10.3138/ $\underline{9781442625082}$

Department of Indian Affairs. (1933, June 26). Report to Superintendent H. McGill on the Depression in Nova Scotia. Library and Archives Canada (LAC. RG10, Volume, 3220, File - 536,764-1).

Ellingson, T. (2001). The myth of the noble savage. University of California Press. https://doi.org/ $\underline{10.1525 / 9780520925922}$

Federal-Provincial-Territorial Directors of Income Support. (2016). Social assistance statistical report: 2009-2013. https://www.canada.ca/en/employment-social-development/services/socialassistance/reports/statistical-2009-2013.html\#h2.1

Forbes, E. R. (1993). The 1930s: Depression and retrenchment. In E. R. Forbes \& D. A. Muise (Eds.), The Atlantic provinces in Confederation (pp. 272-305). University of Toronto Press. https://doi.org/10.3138/9781442657007-011 
Fortier, C., \& Hon-Sing Wong, E. (2019). The settler colonialism of social work and the social work of settler colonialism. Settler Colonial Studies, 9(4), 437-456. https://doi.org/10.1080/ $\underline{\text { 2201473X.2018.1519962 }}$

Fraser, J. (1905, July 21). Report of the Indian agent for Richmond County. Brook Village. In Annual report of the Department of Indian Affairs, 1905. http://central.bac-lac.gc.ca/.item/?id=1905$\underline{\text { IAAR-RAAI\&op }=\mathrm{pdf} \& \mathrm{app}=\text { indianaffairs }}$

Gonzalez, E. B. (1981). Changing economic roles for Micmac men and women: An ethnohistorical analysis (Canadian Ethnology Service Paper No.72). National Museums of Canada. https://doi.org/10.2307/j.ctv16vf1

Gonzalez, E. B. (1982). An ethnohistorical analysis of Micmac male and female economic roles. Ethnohistory, 29(2), 117-129. https://doi.org/10.2307/481372

Government of Canada. (1896). Financial statements, tabular statement B, expenditure for Nova Scotia Indians. In Annual Report of the Department of Indian Affairs, 1896. http://central.baclac.gc.ca/.item/?id=1896-IAAR-RAAI\&op=pdf\&app=indianaffairs

Government of Canada. (1920). Table No. 6. Sources and value of income. In Annual report of the Department of Indian Affairs, 1920. http://central.bac-lac.gc.ca/.item/?id=1920-IAAR$\underline{\text { RAAI\&op }=\text { pdf\&app }=\text { indianaffairs }}$

Government of Canada. (2014). Indigenous and Northern Affairs Canada. Income assistance: Key facts. https://www.sac-isc.gc.ca/eng/1369766807521/1533307648913

Haddad, T., \& Spivey, M. (1992). All or nothing: Modernization, dependency and wage labour on a reserve in Canada. Canadian Journal of Native Studies, 12(2), 203-228.

Haigh, E. (2000). They must cultivate the land: Abraham Gesner as Indian commissioner, 18471853. Journal of the Royal Nova Scotia Historical Society, 3(1), 54-71.

Hanrahan, M. (2008). Resisting colonialism in Nova Scotia: The Kesukwitk Mi'kmaq, centralization, and residential schooling. Native Studies Review, 17(1), 22-45.

Hanrahan, M. (2016). Making Indigenous culture the foundation of Indigenous governance today: The Mi'kmaq rights initiative of Nova Scotia, Canada. Native American and Indigenous Studies, 3(1), 75-95. https://doi.org/10.5749/natiindistudj.3.1.0075

Harell, A., Soroka, S., \& Ladner, K. (2014). Public opinion, prejudice, and the racialization of welfare in Canada. Ethnic and Racial Studies, 37(14), 2580-2597. https://doi.org/10.1080/ $\underline{01419870.2013 .851396}$

Hawthorn, H. B. (Ed.). (1966). A survey of the contemporary Indians of Canada: A report on economic, political and educational needs and policies (Vol. I). Indian Affairs Branch.

Helin, C. (2006). Dances with dependency: Indigenous success through self-reliance. Orca Spirit Pub. 
High, S. (1996). Native wage labour and independent production during the "era of irrelevance." Labour /Le Travail, 37, 243-264. https://doi.org/10.2307/25144044

Hornborg, A. C. (2016). Mi'kmaq landscapes: From animism to sacred ecology. Routledge. https://doi.org/10.4324/9781315595375

Howe, J. (1843). Report on Indian Affairs (RG1, Vol. 430, no. 191). Nova Scotia Archives and Record Management.

Howard-Wagner, D., \& Kelly, B. (2011). Containing Aboriginal mobility in the Northern Territory: From protectionism to interventionism. Law Text Culture, 15, 102-134.

Inwood, K. (1991). Maritime industrialization from 1870 to 1910: A review of the evidence and its interpretation. Acadiensis, 21(1), 132-155.

Ives, N., Denov, M. S., \& Sussman, T. (Eds.). (2020). Introduction to social work in Canada: Histories, contexts, and practices. Oxford University Press.

Jenness, D. (1977). The Indians of Canada ( $7^{\text {th }}$ ed.). University of Toronto Press. https://doi.org/10.4095/306146 (Original work published 1932)

Lescarbot, M. (1928). Nova Francia: A description of Acadia, 1606. Harper and Brothers.

Lutz, J. S. (2008). Makuk: A new history of Aboriginal-White relations. UBC Press.

MacLeod, J. D. (1906). Report of the Indian agent for Pictou County. Annual report of the Department of Indian Affairs, 1906. http://central.bac-lac.gc.ca/.item/?id=1906-IAAR-RAAI\&op= pdf\&app=indianaffairs

McDonald, R. (1884). Report of the Indian agent, District No.7 Pictou, Nova Scotia. In Annual report of the Department of Indian Affairs, 1884. http://central.bac-lac.gc.ca/.item/?id=1884-IAAR$\underline{\text { RAAI\&op }=p d f \& a p p=i n d i a n a f f a i r s}$

McGill, H. W. (1934). Report of the deputy superintendent general of Indian Affairs. In Annual report of the Department of Indian Affairs, 1934. http://central.bac-lac.gc.ca/.item/?id=1934-IAAR$\underline{\text { RAAI\&op }=p d f \& a p p=i n d i a n a f f a i r s}$

McGillivray, A. F. (1876). Report for Indian District no. 8. Grand Narrows, Cape Breton. Annual report of the Department of Indian Affairs, 1876. http://central.bac-lac.gc.ca/.item/?id=1876-IAAR$\underline{\text { RAAI\&op}=p d f \& a p p=i n d i a n a f f a i r s}$

Midgley, J. (1997). Social welfare in global context. Sage. https://doi.org/10.4135/9781483327945

Miller, V. P. (1976). Aboriginal Micmac population: A review of the evidence. Ethnohistory, 23(2), 117-127. https://doi.org/10.2307/481512 
Miller, V. P. (1995). The Micmac: A maritime woodland group. In R. B. Morrison \& C. R. Wilson (Eds.), Native Peoples: The Canadian experience (2 ${ }^{\text {nd }}$ ed., pp. 347-374). Oxford University Press.

Monaghan, J. (2013). Settler governmentality and racializing surveillance in Canada's North-West. Canadian Journal of Sociology, 38(4), 487-508. https://doi.org/10.29173/cjs21195

Mrazek, C. (2017). “After planting their few potatoes they wander about the Island”: The Mi'kmaq and British agricultural policies in nineteenth-century Nova Scotia. Journal of the Royal Nova Scotia Historical Society, 20(19), 18-36.

Neu, D., \& Graham, C. (2006). The birth of a nation: Accounting and Canada's First Nations, 18601900. Accounting, Organizations and Society, 31(1), 47-76. https://doi.org/10.1016/j.aos.2004.10.002

O'Connell, A. (2013). The deserving and non-deserving races: Colonial intersections of social welfare history in Ontario. Intersectionalities: A Global Journal of Social Work Analysis, Research, Polity, and Practice, 2(1), 1-23.

Papillon, M. (2015). Playing catch-up with ghosts: Income assistance for First Nations on reserve. In D. Beland \& P. M. Daigneault (Eds.), Welfare reform in Canada: Provincial social assistance in comparative perspective (pp. 323-328). University of Toronto Press. https://doi.org/10.3138/9781442609730-022

Parnaby, A. (2008). The cultural economy of survival: The Mi'kmaq of Cape Breton in the mid-19th century. Labour / Le Travail, 61, 69-98.

Parnaby, A. (2011). Indigenous labour in mid-nineteenth-century British North America: The Mi'kmaq of Cape Breton and Squamish of British Columbia in comparative perspective. In L. Fink (Ed.), Workers across the Americas: The transnational turn in labor history (pp. 109-135). Oxford University Press. https://doi.org/10.1093/acprof:oso/9780199731633.003.0011

Patterson, L. L. (1985). Indian Affairs and the Nova Scotia Centralization Policy[Unpublished Master's thesis]. Dalhousie University.

Paul, D. N. (2006). We were not the savages: Collision between European and Native American civilizations ( $3^{\text {rd }}$ ed.). Fernwood.

Pedley, F. (1908). Report of the deputy superintendent general of Indian Affairs. In Annual report of the Department of Indian Affairs, 1908. http://central.bac-lac.gc.ca/.item/?id=1908-IAAR$\underline{\text { RAAI\&op }=\text { pdf\&app }=\text { indianaffairs }}$

Pedley, F. (1911). Report of the deputy superintendent general of Indian Affairs. In Annual report of the Department of Indian Affairs, 1911. http://central.bac-lac.gc.ca/.item/?id=1911-IAAR$\underline{\text { RAAI\&op }=\text { pdf\&app }=\text { indianaffairs }}$ 
Reed, H. (1895). Report of the deputy superintendent general of Indian Affairs. In Annual report of the Department of Indian Affairs, 1895. http://central.bac-lac.gc.ca/.item/?id=1895-IAAR$\underline{\text { RAAI\&op }=p d f \& a p p=\text { indianaffairs }}$

Reid, J. G. (2004). Britannica or pax indigena? Planter Nova Scotia (1760-1782) and competing strategies of pacification. Canadian Historical Review, 85(4), 669-692. https://doi.org/ $\underline{10.1353 / \mathrm{can} .2005 .0043}$

Reid, J. G. (2009). Empire, the Maritime colonies, and the supplanting of Mi'kma'ki/Wulstukwik, 17801820. Acadiensis, 38(2), 78-97.

Robertson, T. (1936, June 9). Survey of Indian conditions in the Maritime Provinces (LAC. RG 10. File 536,764-1). Library and Archives Canada.

Sager, E. (1987). Dependency, underdevelopment, and the economic history of the Atlantic provinces. Acadiensis, 17(1), 117-137.

Samson, D. (2008). The spirit of industry and improvement: Liberal government and rural-industrial society, Nova Scotia, 1790-1862. McGill-Queen's Press.

Santos, T. (1970). The structure of dependence. The American Economic Review, 60(2), 231-236.

Sargent, J., Monk. G. W., Tonge, C., Morris, C., \& Mortimer, E. (1800, April 15). Report of the commissioners appointed to inquire into \& to report on the condition of the Indians in the province (Nova Scotia Archives and Record Management, RG 1, Volume 430, Document 33, 1/2). Nova Scotia Archives.

Shewell, H. (2004). "Enough to keep them alive": Indian welfare in Canada, 1873-1965. University of Toronto Press.

Shewell, H., \& Spagnut, A. (2002). The First Nations of Canada: Social welfare and the quest for selfgovernment. In J. Dixon \& R. P. Scheurell (Eds.), Social welfare with Indigenous Peoples (pp. 1-53). Routledge.

Simon v. Canada, [2012] F.C. 387, T-1649-11. https://decisions.fct-cf.gc.ca/fc-cf/decisions/en/item/ 60730/index.do?r=AAAAAQAWU2FuZHJhIFNpbXBzb24gd2VsZmFyZQAAAAAB

Spragge, W. (1873). Report of the deputy superintendent general of Indian Affairs. In Annual report of the Department of Indian Affairs, 1873. http://central.bac-lac.gc.ca/.item/?id=1873-IAAR$\underline{\text { RAAI\&op}=p d f \& a p p=i n d i a n a f f a i r s}$

Steen, S. C. (1951). The psychological consequences of acculturation among the Cape Breton Micmac [Unpublished Master's thesis]. University of Pennsylvania.

Taylor-Neu, R., Friedel, T., Taylor, A., \& Kemble, T. (2019). (De)constructing the "lazy Indian": An historical analysis of welfare reform in Canada. Aboriginal Policy Studies, 7(2), 65-87. https://doi.org/10.5663/aps.v7i2.29340 
Trefry, H. S. (1924, December 20). Correspondence with the Department of Indian Affairs regarding centralization of Nova Scotia's Indians (LAC. RG 10, Vol 3220. File - 536,764-1). Library and Archives Canada.

Union of Nova Scotia Indians. (2013). The health of the Nova Scotia Mi'kmaq population: Results from the 2008-10 Survey for the on-reserve population.

Upton, L. F. S. (1973). Origins of Canadian Indian policy. Journal of Canadian Studies, 8(4), 51-61. https://doi.org/10.3138/jcs.8.4.51

Upton, L. F. S. (1975). Indian policy in colonial Nova Scotia 1783-1871. Acadiensis, 5(1), 3-31.

Wallerstein, I. (2011a). The modern world-system II: Mercantilism and the consolidation of the European world-economy, 1600-1750. University of California Press. https://doi.org/ $\underline{10.1525 / 9780520948587}$

Wallerstein, I. (2011b). The modern world-system III: The second era of great expansion of the capitalist world-economy, 1730s-1840s. University of California Press. https://doi.org/ $\underline{10.1525 / 9780520948594}$

White, R. (1988). The roots of dependency: Subsistence, environment, and social change among the Choctaws, Pawnees, and Navajos. University of Nebraska Press.

Whitehead, R. H. (1991). The old man told us: Excerpts from Micmac history, 1500-1950. Nimbus Publishing.

Wicken, W. (1991). Mi'kmaq Land in Southwestern Nova Scotia, 1771-1823. In M. Conrad (Ed.), Making adjustments: Change and continuity in planter Nova Scotia, 1759-1800(pp. 113-146). Acadiensis Press.

Wicken, W. (2002). Mi'kmaq treaties on trial: History, land, and Donald Marshall Junior. University of Toronto Press. https://doi.org/10.3138/9781442670211

Wien, F. C. (1986). Rebuilding the economic base of Indian communities: The Micmac in Nova Scotia. Institute for Research on Public Policy/L'Institut de recherches politiques.

Wien, F., Denis, J., Dockstator, J. S., Dockstator, M. S., Duhaime, G., Loppie, C., Loxley, J., Moore, C., Newhouse, D., Weir, W., Whiteduck, J., \& Wuttunee, W. (2019). First Nation paths to wellbeing: Lessons from the Poverty Action Research Project. Global Health Promotion, 26(3), 616. https://doi.org/10.1177/1757975919831654

Wilkins, D. E. (1993). Modernization, colonialism, dependency: How appropriate are these models for providing an explanation of North American Indian 'underdevelopment'? Ethnic and Racial Studies, 16(3), 390-419. https://doi.org/10.1080/01419870.1993.9993789 
Young, T., Ginnish, D., \& the Mi'kmaq Association of Cultural Studies. (2017). Tptinewey: Mi'kmaq Elders' perceptions of social assistance. Report for the Building a Social Policy Framework for Mi'kmaq communities: A Two-Eyed Seeing approach. Cape Breton University. 